\title{
Sønderjylland 1925.
}

\section{Af Thade Petersen.}

\section{Gransen.}

Arbejolet med Gransedragningen i 19:0 lod sig for saa virlt marke endnu i 1925, som Opgarels en a fid gifterne til den internationale lommission nu forelaa. De udgjorde $3,388,46 \% \mathrm{Kr}$., hvoraf $1,860,(612 \mathrm{Kr}$. var gaact til den militare Besarttelse (I. 20. 2.).*)

Et af de Forhold, (irensedragningen har nodvendiggjort, er den gensidige $I$ d l e vering a $\Lambda \mathrm{Ar}$ i valier, som der endnu arliejdes med. (II. 21). 4.).

De tyske Befastningsanlag i Nordslesvis er nu i det vasentlige bortsprangt. Veal Over Jersalal er de borte (H. :2(;. 8.).

Fardslen over Gransen lettes efterhanden for en hel Del af de Vanskeligheder, len lider under fra Krigstiden. I)en tyske Told- og Pasrevision, der hidindtil kıravede Udstigning i Harreslev, sker nu i Toget (H. 14. 4.). Alligevel er der endnu Vanskeligheder nok tilhage, Navnlig Pastvangen. I en Omtale af forskellige sonclerjydske Forhold bragte Pastor Schmidt den yaa Tale i Folketinget og krævede den opharet (Iv. 14. og 1.). 11.). Noget senere fremkom et lignende Krav fra tyske Erhvervsorganisationel (Av. 26. 11.). Den :9. 4. bragte Fl. Av. en Oversigt over Antallet af Rejserno over Gransen ved de forskellige Overgangssteder i 1924. Midt i $A$ ugust standsede Handelen over Gransen nasten fuldstandig som Folge

*) H. = Hejmdal, Av. = Flensborg Avis, Lhr. = Nordslesvigsk Landbrugs- og Mejeritidende 1925. 
af kronons hurtige stigning (II. 19. 8.). For mange, navnlig ved Giransen, lagde Mund- og Klovesygen en slem Hirdring i Vejen for Fardslen. Fn tysk forordning forlwd Landmarudene ved Gransen at fore klovbarende Dyr over denne ogsaa til Marker, de selv ejede paa den anden Side af den. (II. 1x. 5.). Fra tysk Side blev der andraget om Lov for Landmand til at passere (iransen ved nogle sekundirre Overgangssteder. (H. 228. 7.). Og i Begyndelsen af September blev der grivet nogle Landmand Nord for Grænsen 8 Dages Tilladelse til al huste deres Koln paa Marker, de ejede syd for denne. (If. 3. 9.).

Fin tysk sitle liom der et I'ar liange store Selskaber over i festlige ojemed. Ret uskyldigt var et Besøg i

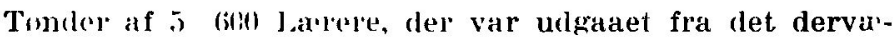
rende seminar. Ikko mindst ved dansk Imolekommenhed tik dot et upraklageligt Forlob. (Av. 4. 4.). Mindre lysteligh var et tysk Forsug paa at skaffe sig dansk Hjaly, til et Jesng verl hinivsjjergfesteru. De ansugte om Fællesrisum for et Par Tusinde. Dette blev dem ganske vist nargtet. lorimoil blev det givet dem for 420 Personer. Over renme Nirgtelse blev der i tyske Blade gjort stor Larm, mens en Redegurelse fra den danske Generalkonsul viste, at der fra dansk side var vist dem vidtgaaende Imolekormmentied (II. 1., i., 7., 11). 1). og 21;. 9. Av. 3. og 4. 9. fif.).

Bevogtningen af (iransen kom ved Aarets Begyndelse starkt paa Tale (Av. 11. 1.). Marhus Amtstidende fremkom med en Foresporgsel, om det var muligt at afvalge Inclfald af tyske Friskarer. Herpaa svarede General Moltke, at Militaret i givet Tilfalde kunde kaldes 1 il IIjarlp. Imidlertid fremkom der Meddelelse om, at "Nordslesvigs Jefolkning organiserer et Gransevarn" med Bankdirektur lRossen i Tunder og (iaardejer Cornelius Petersen, Vesta Anflod, som ledere (II. 24., 26. og 27. 1., 2., 3. og 14. 2., 10. 3., Av. 27. og 30. 1., 1. 2.). I Sammenhang med dette hore stod vel et $\Delta$ ndragende fra Granse- 
gendarmerne om at faa Pistoler i stedet for Geverer (H. 14. 8.).

De fai Udtalelser af Botylning, der i Aarets L sattes om Gransedragningen, viser $i$ Retning ad stadig voksende Anerkendelse af den. I en Bog om „Staatsbürgerliche Beziehungen« skriver Professor VeitValentin bl. a. "Overfor Danmark er kun gammel Iref gjort godt igen «. I den Anledning rettede Jane Voigt og Schröter ganske vist en Foresporgsel til cien preussiske Landdag og paastod, at "slesvig-IIolstens Befolkning ikke anerkendte den nuvarende (iranse som retmassig (II. 27. 1.), men "Flensburger Volkszeitung“ skrev senere (H. 15. 7.), at (irænsen maatte anerkendes som om end ikke retfærdig, sua dog $\mathrm{i}$ sine vasentligste Dele fastlagt ved frolkets Flertals Vilje. Der bor derfor virkes for en Forstaaelse mellem dansk og tysk. Og "Deutsche Zukunft" skrev: "Afgorelsen i 1920 har nu en Gung skaffet en sikker Basis for en fuldstandig Forstataelse mellem begge Folk" ( $H$. 2. 10.), mens Neve Zürcher Zeitung fremhavede, at den dansk-tyske Granse ikke horte til Europas Urocentre $(H$. 7. 11.), og Professor Scheel i en Tale i Kiel sagde, at Udviklingen i det nationale sporgsmaal maatte bedommes paa langere Sigt. Han kunde om det tit vare enig med "Hejmdal" (H. 3. 12.). Denne Udvikling paapegede H. P. Hanssen i sin Tale ved Genforeningsfesten i Aabenraa og gjorde udforlig Rede for den (H. 17. 6.). Fra dansk Side kommer Tanken om en Flytning af Grænsen nu sjælden og kun glimtvis frem. (II. 4. 11.).

Ubeherskede fanatiske Udtalelser saavel fra dansk som fra tysk Side har dog ogsaa i Aar lejlighedsvis forplumret Forholdet mellem Danske or Tyske. Saaledes fremkom der $\mathrm{i}$ "Landmandstidende" en taabelig ArtikeI om tysk Kanibalisme, der vakte stort Røre i visse tyske Kredse (H. 13., 21., 22., 24. og 28. 1., Av. 22., 23. og 27. 1.). En dansk Forfatter, Thorkild Gravlund, begik desvarre ogsaa en Ubesindighed at beklage de Skridt, der 
var gjort for at hiclfore en Codsoning i Gransestriden (H. 9. 2.).

Det vigtigste Gransesporgsmat ev jo det om Mindretallets Ret paa begge sider. Fra dansk Side blev der jo straks givet det tyske Mindretal Nord for Grænsen upaaklagelige Kaar. bot anerkendes fra Udlandets Side. Saaledes bringer det amerikanske Ugeskrift "The Nation« en Artikel om Norlslesvig under Overskriften: "It ikke undertrykt Mindretal«. (11. 20. 6.). Nu og da finder det ogsaa - om end med en Del Forbehold Anerkendelse fra tysk Side. Saaledes bl. a. i en Artikel af Pastor Muus i Tating (H. 14. 1.) og J. Budewadt i "Berliner Borsenzeitung« (II. 14. (i.) (Se ogsaa uncler $2 \mathrm{c}$ ).

Pa ragraf 5, som danner ilundlaget for Grænsedragningen, kom i Lar starkt frem i liskussionen, idet det tyske Udenrigsministerium ved Platzhoff og Rheindorf udgav en Bog om Bismarck og \$ 5 (II. 9. 2.), der dog var s4a mangelfuld og til Dels tendentios, at clen straks fremkaldte stærk Kritik baade fla dansk oy tysk Side (H. 10., 16., 17., 25. 2., 16. 4., 20. 5. Av. 14. 2.). Detto Stykke tysk. Historiegranskning blev snart saa medtaget af Kritikken, at det tyske Udenrigsministerium saa sig nodsaget til at foranstalte et Supplementshind udgivet under Professor Scheels Ledelse. (H, 1.5. 7.).

\section{Nationalt Liv ved Grensen.}

a) d a n s S y d for G r a n e n.

Fra tysk Side bragte 1925 endnu $\mathbf{i k}$ k e nogen ord$\mathrm{n}$ in $\mathrm{g}$ af det danske Mindretals Forhold. Dr'rimod marker man hele Aaret igennem Kampen mellem Regreringen i Berlin og chauvinistiske slesvigholstenske Kredse om Formen for den Ordning, der maa tratfes. I en fortrolig Skrivelse til sine stedlige Afdelinger fremsatte saaledes Schleswig-Holsteinerbund sine Tanker og Onsker vedrorende Mindretalsretten. Det vesentlige i denne var, at den skulde baseres paa privat Kulturautonomi. Denne 
Skrivelse, der val forfattel af Nhere Wacker, vakte Modstand selv hos Tyskerne. Pastor Schmidt tog Afstand fra den, og Pastor Muus i Tating betegnede hans Forslag som en "uxrligr Mindretalsret" samtidig med, at han havdede, at Mindretallene havde en menneskelig liet til kulturel og national Frihed (H. 3., 5., 13., 14. 1., \v. 13., 14. 1.). Grunden til dette liore hos "Sichleswig-Holstenerne" var vel Frygten for, at Regeringen vilde gennemfore en ordning af anden Art. Denne begyndte nemlig ved den Tid at rore paa sig. Den 13. 1. var lieprasentanter for den i kiel for at drufte Sagen med P'rovinslanddagens Timandsulvalg og Dagen derefter i Flenshorg for at dlofte den med Dansk Skoleforening. (Av. 1.)., 16. 1., 11. 1.). 1.). I den ple ussiske Landdar fremsatte socialdemokmaterne et Forslag til en Ordning (H. 7. 2.). Lt andet, baseret paa Privatskolen fremsattes af Timandsudvalget (II. 18., 19., 201. 2. Av. :20, "2:. 2.) og i Flenshorg fandt der nye Forhandlinger sted mellem tyske Myndigheder ogr den danske Skoleforening (II. 24. 2.). Ogsaa i Rigsdagen fremkom ot Forslag (HI. 16. 6.). Endelig midt i september hed det, at nu var ordningen narl forestaaende (II. 14. 9.) og sidst i Oktober blev Dansk Skoleforenings Bestyrelse i Flenshorg kaldt til Berlin. (II. 30. 10.). Alligevel gik Aaret hen uden Resultat.

Paa Folkeforbundsforeningernes Inionsmode i Warszawa 3.-8. 7., kom sporgsmaalet om dansk og tysk Mindretalsret ikke til Forhandling, men der blev fremlagt en Frklaring fra don tyske "I,iga für Völkerbund" og et Svar fia Amtsskolekonsulent Svendsen og Professor Friis paa Dansk Fredsforenings Vegne (II. 9., 22. 7.).

Senere fremkom in Berelning om Droftelsen paa hon ferencen i c i nè ve vodrenende Mindretalsretten. Det dunske Mindretal afholdt sig her Ira at stemme om Forslaget om Kulturautonomi (H. 19., 20., 26. 10., 12. 11., Av. 18., 20., 22., 23., 24., 25., 27. 10., 12. 11.). 
Mens Regeringen i Berlin af IJensyn til de tyske Mindretal ved sine andre Grænser ujensynligt har onsket at gennemfore en god og redelig Mindretalsoraning her oppe, har de nationalistiske Kredse i Provinsen strittet haardt imod, mens dog enkelte Røster har loftet sfg for en arlig og redelig Ordning (H. 26. 2., 6. 3., 6. 5., 9. 5., 26. 8., 27. 10. Av. 9. 5.). Hele Mindretalspongrsmaalets Gang giver »Grænsevagten" en udforlig samlet Fremstilling af i sine Maanedsnoter for 1925 .

Alt imens blev der holdt d a n sk $\mathbf{s} k$ ole i Flensborg under de Kaar, der nu en Gang var. Duborgskolen blev forelubig fritaget for den officielle Prove (Av. 8. 4.) og den havde godt Besgg. Der afgik fra den 88 , (deraf 22 med Præliminæreksamen (Av. 1. 4.)), mens 157 blev optaget. deriblandt dog 50, der overiortes fra den danske Privatskole, som Tyskerne havde lukket den 1. 4. (H. 3. 6.). Paa sin j Aars Fodselsdag fik den af Statsskolerne i Nordslesvig et smukt Dannebrog med Indskrift i Guld. Der blev givet en Oversigt over dens Udvikling. (Av. 16. 10). I Harreslev blev der stadig lagt Hindringer i Vejen for Oprettelse af en dansk Klasse (Av. 29. 8., H. 29. 8.) og i Jaruplund nægter Skole- og Kommunerepræsentationen at tage Stilling til et Andragende om en dansk Klasse (Av. 4. 9.). Imidlertid søger stadig et betydeligt Antal af unge over til Hoj- og Efterskoler Nord for Gransen, saaledes 218 i 1924 (Av. 20. 5., H. 20. 5., 19. 8.).

Fra Kirkelivet meddelte det tyske Menighedsblad i Flensborg, at Kirkestyret var stemt for at afslaa alt Fællesskab med en Præst fra den danske Menighed ved Udfixrelsen af kirkelige Handlinger. Hvad der er udført ved dem skal ikke en Gang indfores i Kirkebogen (H. 26. 2.). For den danske Menighed i Flensborg har det ellers været et stille Aar med Uddybelse af Arbejdet. Der har været 1343 Nadvergæster, 51 er bleven døbt, 120 konfirmeret, 18 Par viet, 41 begravet. Den har 3010 Medlemmer, deriblandt 910 Bırn (Av. 19. 5.). Ved Afskedsfesten for Pastor Moos 
sagde Pastor Noack, at Menigheden i den Tid, Moos var der, var vokset fra 1800 til 3000 Medlemmer, Gudstjenesternes Antal var bleven fordoblet, Kirkebesiget var voliset, det kristelige Arbejde $i$ og uden for Flensborg befestet, faste Annekser oprettet i Harreslev og Slesvig o. m. u. (Av. 27. 8.).

Fra $\mathrm{II}$ ode- og Forenings livet skal kun narnes, at en dansk Ungdomsuge den 16 . 3 . begyndte med et godt Mode i Valsbol og de folgende Dage fortsattes med Inoder forskellige steder. (Av. 17. 3. ff.). Lngdomsforeningen for IIarreslev og Omegnen holder Mode hver Onsdag Aften med Foredrag og (Oplasning (Av. 23. 1.). Sygeplejeforeningen i Flensborg har taget sig af 563 Patienter. (Av. 10. 2.). Den 1i. 1. talte P'rofessor Vilh. Andersen ved et Folkeuniversitetsmode i Flensborg for fuldt Hus. (Av. 17. 1.). En dansk Forestilling paa Theatret i Flenshorg fik Byraadet endnu dette Aar forhindret ved at nogte Tilladelse til den. (II. 23. 4.). Et Par Dage for havde Peter Cornelius sunget for fuldt Hus i Borgerforeningen (Av. 23. 4.'. Denne fejrede den 15. Maj sin 91. Stiftelsesdag (Av. 14. 5.). Den slesvigrske kvindeforening har haft et godt Arbejdsaar. (Av 13. 5.). Dansk skoleforening i Flenshorg holder Aarsmode den $1 \mathrm{x}$. 5. Den har 1259 Medlemmer (Av. 20. 5. 11, 20. 5.). I det 5. danske Aarsmode i Flensborg d. 7. 5. deltog ca. 4501). Den slesvigske Forening har 50\%0 Medlemmer. Fra Bcysamlingen i Flenshorg er udiaant $44,9 \times 4$ Bind. Paa Landet har Foreningen staaet stille, men holdt Stillingen (II. 8. (i., Av. 9. 6.). Et sydslesvigsk Ungdomsstervne i Talup d. $2 x$. j. samlede ca. (60) Deltagere. St. Knudsgilde fik af Advokat Ravn en Sum Penge, der var bleven givet ham som Hadersgave i Anledning af, at Tyskerne havde afsat ham som Notar (Av. 14. 8.). Den 4. 10. indviedes $€$ n ny Sal i Ung. domshjemmet i Flensborg (II. 5. 10., Av. (i. 10.). Den 22. 11. holdtes et godt Foredragsmade i Bilskov (Av. 22. 11.).

P re s s e n skyder et nyt Skud, idet Tidsskriftet "Kul. tul'wille« begynder at udkomme. Det er Organ for de dan- 
ske, frisiske, polske og vendiske Mindretal i Tyskland. Det redigeres i Berlin, men trykkes i "Flenshorg Avisus Trykkeri (Av. 31. 5. H. 2. 16.).

De paa Tysk sk revne danske Blade slaaes sammen til et "Der schleswiger", der redigeres i Flenshory og trykkes i "Flenshorg Avisus Trykkeri (II. 11). 7.).

Ved V a l g e t 29. 11. valgtes en dansk hiedsulagsmand i Flensborg Landkreds, 2 i Slesvig Krerls og én frisisk $i$ Sydtunder Kreds (Av. 1. og 2. 12., H. 36. 11., 1., 2., 3. 12.).

Mindretallenes $\mathrm{St}$ ir relse baade Nord og syd for Gransen gav Lebeck en Oversigt (og et liort) over (II. 4., 5. 11.).

Tyske Drilleritr er naturligvis ikke helt undgatet. Til Gengald for at sende »Flensborg Avis« Byens Annoncer til $g \mathrm{r}$ a t is Optagelse forlanger Overborgmester Todsen, at den skulde afholde sig fra Angreb paa Myndighederne (H. 16. 1.). Den 1. 9. var en Del spejdere fra Flensborg udsat for tyske Forulempelser i Valsbol (Av. 1. or :2. 9.).

Den danske si pa re- og La a n k a se i Flensborg holdt 10. 10. 50 Aars Jubilaum (Av. 8. 10).).

Det danske Mindretal syd for (nansen har paa forskellig Maade faaet $S \mathrm{t}$ \& $\mathrm{t}$ t e Nord fra. Deriblandt 200,000 hr. fra den danske Stat til kulturelt Arbejoie. For Anvendelsen af den gor Folketingsmand (i. Fogh-Petersen Rede (H. 18. 4., T. 10.). Sunderjydsk Skoleforening anvendte $20,(0100)$ Kr. til Arbejde Syd for Gransen (H. :2(j. 11). (3., 9., 17. 11., Av. 30. 10.). Rigelig 37.0100 Kr., der er indsamlet til "silesvigsk Hjælpefond" er hovedsagelig bleven anvendt til Mad og Klader (H. 7. 12.).

b.) tysk Syd for Grænsen.

Hojskolen i Rendsborger vel nok noget af det hedste og mest livskraftige, Tyskerne i Slesvig og Holsten har skaht efter hrigen. I Februar forlod det, at den skulde udvides med et folkepædagogisk Seminar (H. 20. 2.). Se- 
nere var der Tale om at sætte udvidede 8 Ugers Kursus $\mathrm{i}$ Gang (H. 15. 5.). Der hlev dog nok intel af dette gennemfort i det Aar.

Betegnende for Maalet af Frihed i preussiske S k o l e r, selv nu, er det, at Lærerne ved Skoler i frisiske Egne har faaet Overpræsidentens Tilladelse til at lade Bornene læse nogle Stykker Frisisk - deres eget Modersmaal! (H. 26. 2.).

En Mand (Timmermann), der en Tid lang sngte Tilslutning til Danske, viser sig nu som tysk og virker for Dannelse af et $J$ or d f on d, der skal bevare Gaarde paa tyske Hænder. (H. 9. 12.). Til Oprettelse af $\mathrm{H} \mathrm{jem}$ for L a n d a r bejd ere faar de nordligste Amter 150,000 Mk. af Staten (H. 24. 7.). Imidlertid har Tyskerne i Flensborg lidt den Tort, at Frihavnen, der for Afstemningen vinkedes saa stærkt ad dem med, ikke bliver andet end et "Toldudelukkelsesomraade", der oven i Købet bortforpagtes for 50 Aar. Danskerne i Byraadet og 9 andre lod dem selv sabe Kaalen ved ikke at stemme. (Av. 6. 8.).

Til Biskop for den sl. holst. Landskreds valgtes Völkel. (Av. 8. 1.). Han indviedes 15. 4. (Av. 16. 4.).

\section{c. tysk Nord for Grænsen.}

I et Par Artikler $i$ "Hejmdal" gav A. Lebeck et Billede af $\mathrm{T} y \mathrm{skhedens} \mathrm{V} æ \mathrm{kst} \mathrm{i}$ Sønderjylland under det tyske Styre (H. 25., 27. 7.).

Et betydeligt $T$ a b a f $E$ jend omme led Tyskerne, idet Baron Rombergs Arvinger solgte Gammelgaard, Rumohrsgaard og Wertemine til den danske Stat for 2,230,000 Kr. (H. 27., 30. 11., 1. 12., Av. 28. 11.). I det hele er Jord $i$ tysk- Eje gaaet stærkt tilbage siden Genforeningen. Af Gaarde med over 100,000 Kr. Ejendomsskyld havde de før 192054 pCt. af Arealet, 1922 kun 24 pCt. (H. 18. 12.).

At mange af Tyskerne har dansk Modersmaal, finder man længere Syd paa betænkeligt (H. 10., 12. 11.). Maaske for at sprede disse Bekymringer gav et Par Med- 
lemmer af Sonderborg Byraad, fodt og opvokset paa Als, sig til at tale Tysk (H. 17. 12.). I Aabenraa tiltvang tyske Socialdemokrater sig som Folge af altysk Agitation Ret til at holde Moder med tysk Forretningssprog (H. 6., 16., 24. 7.).

At de be hand les god t fra dansk Side, kan de ikke helt nægte. Baade Overskoleraad Ehrt fra Slesvig og Ungdomsleder Christensen fra Aabenraa indrommede det paa et Møde i Pinneberg. (H. 30. 7.). Ligeledes en Medarbejder ved "Deutsche allgemeine Zeitung" (H. 17. 8.). De, der har »tappet den nationale Ophidselse og Lidenskab paa Flasker«, taber derfor Terræn. (H. 24. 8.) Uenighed mellem disse og de mere maadeholdne bryder da ogsaa undertiden frem. (H. 8., 9., 10. 9.).

Den ty ske Agitation er dog ret rorig. (II. 29., 30. 5., 2. 6., 30. 10., Av. 8. 3.).

Paa kirkeligt $0 \mathrm{mra}$ ade har Tyskerne skabt sig egne Menigheder, der danner et Led af Landskirken i Slesvig-Holsten (H. 3. og 10. 2., Av. 5. 2., 22. 7.). Pastor Horstmann bliver Præst for en saadan i Hacierslev og Omegn (H. 11. 5., 1. 10., 14. 12.). Paa et Provstemade i Haderslev var man enig om at vise disse Menigheder saa megen Imødekommenhed som muligt (H. 26. 6.). I Tinglev har de paa deres Lister opfort Folk uden deres Vidende. (H. 15. 8.). I Haderslev blev Pasior Andersen af det danske Kirkestyre ansat som Præst for Tyskerne i en Rakke Sogne omkring Haderslev (H. 19. 10.). Tyskere i Haderslev forsvarer Biskop Ammundsen mod tyske Angreb paa hans Embedsvirksomhed. (H. 27. 10., 5. 11.). Pastor Prahls Afsked (H. 28. 12.).

Paa S k o le n s O mraade vister der sig en Mangel i Afstemningsreglerne om Mindretalsskoler. De maatte derfor ændres (H. 16. 4., Av. 25. 4.). Utilfredse med Endringen lavede Tyskerne i Bylderup Obstruktion (H. 12. 20., 22. 5., Av. 23. 5.). Forholdene paa dette Omraade gjorde Sinderjydsk Skoleforening udforligt Rede for i en Bro- 
chure (H. 15. 7.). Ogsaa her suger de at frigore sig for dansk Indfydelse, idet de opretter Privatskoler, saaledes i Vilstrup, Skovby, Aabenraa, Logumkloster, Bylderup og Bedsted. (H. 17. og 30. 1., 8. og 12. X., 20). og :23. 10., Av. 5. 10.). Alligevel hliver der ved at vare et betydeligt Antal offentlige tyske Skoler, nemlig 20 med 105 Klasser, der har 24.52 Elfver og 12 Privatskoler med 24 Klasser og 339 Elever, mens der Syd for Gransen kun findes 1 offentlig dansk Skole med 5 klasser og $24: 3$ Elever og 1 privat med 12 Klasser og 364 Elever (H. 3. 9.). Et tysk onske vedrorende Skolen i Sonderborg imıdekom Undervisningsministeren paa en Rejse hernede (H. 1. 10.). I Tunder blev der ikke forebragt hende tyske klager (H. 12. 10.). I Haderslev fordrev Tyskerne en Larer fra den tyske Skole, fordi han havde uddelt et Bonneblad, hvori der fandtes en Vittighed om en tysk Officer. (H. 3. 2., 7. 4.). In tysk Larerinde, Frk. Pohlmann, gjorde stort Vasen af, at hun efter Loven matte trade ud af Kommuneskolens Tjeneste, da hun giftede sig (H. 10. 6.).

Til et $\mathrm{t} y \mathrm{sk}$ Bibliotek bevilgede Haderslev Byraad med Tyskernes, Socialdemokraternes og Borgmesterens Stemmer et Tilskud. Bagefter stemte Tyskerne imod Forhojelsen af Tilskudet til det danske Folkebibliotek (H. 4. 2.). H oj skolen i Tinglev havde fuldt Hus og maatte afvise mange (H. 6. 5.).

Mader og Foreninger har Tyskerne brugt starkt. I Februar holdt deIes Ingdomsforeninger i 3 Dage deres 5. Aarsmode i Tinglev og indviede en slesvigholstensk Fane (H. 25. 2.). Endog i Kobonhavn dannede de en lille Studenterforening med en halv Snes Medlemmer (H. 23. 3.). Nu skal der dog efter Sigende kun vare j. Deres Aarsmode holdt de tyske Organisationer i Hojer med hemmelige Forhandlinger. (H. 18. 8.). Den 6. 9. holdt de deres Knivshjergfest med 4-5000 Deltagere (H. 7. 9.).

Syd fra faar de betydelig $S t a t$ t e til alt dette Arbejde (H. 1., 12., 24. 10., Av. 24. 10., 18. 11.). 
d.) dansk i Nordslesvig.

Som det med Rette blev anset som et Vidnesbyrd om det tyske Herredømmes unaturlige Elendighed, at Befolkningen i Nordslesvig tog af, kan der nu, trods Krigstabene peges paa stærk $\mathrm{T} i \mathrm{l}$ ₹ $\mathrm{ks}$ t som Udtryk for godt og naturligt Styre. Alene i Tonder Amt har der fra 1921 til 5. 11. 1924 været en Tilvækst af 2355 , hvoraf $700 \mathrm{i}^{\prime}$ Tønder By alene. (H. 10. 2., Av. 30. 1.). I hele Nordslesvig viste der sig i samme Tidsrum en Tilvækst af 11,619 , eller 7,3 $\%$, i det øvrige Land $0,96 \%$. Byernes Folkeantal steg gennemgaaende med $11,1 \%$ eller vel endog $12 \%$ (H. 6. 3., 12 11., 12. 12.).

Befolkningens $\mathrm{S}$ a mmens $\boldsymbol{\mathrm { m }} \mathrm{t} \mathrm{n}$ ing $\mathrm{g}$ er for Resten noget ujævn i Nordslesvig. I 1921 viste det sig, at 12 pCt. eller 19,167 var født uden for Danmark; deraf var 6490 fra Sydslesvig (Av. 4. 10.).

Blandt de Valg, der i Aarets Løb fandt Sted, fortjener Skolekommissionsvalget $\mathbf{i}$ Højer at nævnes. I Landsognene vandt Danskerne Flertallet, mens de i Byen gik ind paa et for dem daarligt Forlig (H. 23. 4.). Ved lignende Valg $i$ Haderslev indgik Socialdemokraterne hemmeligt Listeforbund med Tyskerne, hvorved de tabte 685 Stemmer og hjalp Tyskerne til et Mandat (H. 28. 29. 4., 5. 5.). I Bylderup og Udbjerg Sogne satte Danskerne en Mand mere ind i Sogneraadet (H. 12., 13. 3.).

Af det rige $\mathrm{F}$ or en ings $\mathrm{s}$ iv og Mængden af $\mathrm{M} ø \mathrm{~d}$ er skal kun nærnes Grænseforeningens nationale Uge (Av. 8., 10., 17., 24., 25. 2., 3., 10. 3., H. 23., 26. 2.). Blandt disse Møder blev der særlig lagt Mærke til det i Røddng, hvor der fandt et Ordskifte Sted om Dannelsen af en Enhedsfront (H. 26. 2., 4., 7., 24. 3. Av. 6. 3.).

Den 27. 2. fejrede Nustrup med flere Sognes Foredragsforening sit 40 Aars Jubilæum (H. 28. 2.). I Aabenraa sattes det socialpolitiske Kursus igen i Gang i Dagene fra 28. 2.-2. 3. (H. 2. 3.). 
Ved Grænetforeningens Tillidsmandsmode i Sunderborg den 23. 3. viste der sig endnu at bestaa en Forhindelse mellem denne Forening og »(Grænseværnet« (H. 25. 3.), som dog saa vidt vides senere er ophort. Sidst i Marts dannedes der i Haderslev Vesteramt en Afdeling af Grænseforeningen, som især vil stotte Maren Sorensens $\mathrm{cg}$ Niels Kjems' Arbejde Syd for Grænsen. (H. 2t., 27., 28. 3., 1., 3. 4., 24., 28. 11.). Den 23. 5. holdt Foreningen Aarsmode i Haderslev og ved Kjelstrup Strand (H. 25. 5., Av. :2(i. j.). Den har 33, (0)6 Medlemmer (Av. 30. 6., H. 31). 6.).

Ved (iransen holdtes Moder i hollund (2. Pinsedag) (Av. 3. 6.), i Krusaa (H. 13. 7.) og i Froslev Polde (H. :24. 8. Av. 25. 8.).

Den 13. og 14. (j. holdtes der for forste (iang siden 1914 dansk Aarsmode, idet Sprogforeningen og Skoleforeningen holdt Generalforsamling sammen i Vester Sottrup med paafolgende Folkemode paa Dybbol. Skoleforeningen har 12,977 Medlemmer i Nordslesvig og $37 \times 3$ i det ovrjge Land. sprogforeningen har langt fra saa mange, men har haft en Tilvækst af 241. (Av. 14., 16. 6., H. 15. 6.). Ved Mndet paa Dybbal gav H. P. Hanssen en Oversigt over det nationale Arbejde siden Genforeningen.

Den 28. Juni holdt Historisk Samfund for Sonderjylland Aarsmude i Norborg. Det havde 514 Medlemmer (H. 29. 6.).

Det aarlige Sommermode i Vedsted samler nu mange Deltagere, i Aar over 1000) (II. 6. 7.).

Tinglevhus staar nu i 130,600) Kroner (H. 11. 7.).

En Vandreudstilling af ca. 100 Billeder aabnedes 17. 7. i Aabenraa (H. 18. 7.) og i Haderslev (1I. 1. 12.). Lignende Udstillinger har varet afholdt i andre Byer.

Paa Dylbol holdt de danske Ungdomsforeninger i Sonderjylland Stævne med ca. 5000 veltagere (H. 2\%. Nogle Dage for holdt de danske Ungdomsforeninger deres Aarsmade i Haderslev. De har 41,750 Medlemmer. Der var modt. 50) Delegerede (II. 18. 7.). 
Af regelmæssige storre Efteraarsmoder kan nævnes \{lem i Bylderup (H. 21. 9., Av. 22. 9.), Tonder (H. 24. 9.), Rodding (H. 9. 11.) men mange flere afholdtes og samlede mange Mennesker.

I d r t er i god Fremgang. De sonderjydske Idrætsforeninger har ca. 40100 aktive Medlemmer, deriblandt 850) Skytter (H. 20. 1., 7. 9.).

Af $n$ ationale Fester maa isar nævnes Afstemningsdagen, der fejredes rundt om i Landet under stor Deltagelse (H. 11.-14. 2., Av. 11., 12. 2.). En Del Steder fejredes Grundlovsdagen (H. 6. 6., Av. 7. 6.) skunt den har ikke let ved at hævde sig blandt de særlige sinderjydske Fester. Genforeningsdagen (15. 6.) gav ikke Anledning til saa mange, men dẹrimod vist til saa meget større Sammenkomster, for en stor Del i det fri. (H. 16., 17., 18. 6.). Ogsaa Kongens Fodselsdag fejredes mange Steder som national Festdag.

Af betydningsfuldere $B$ es $n g$ maa nævnes "Nordisk administrativt Forbund« i Tonder, Aabenraa og Haderslev (H. 2. 7.) og Ryslinge Hojskoles særdeles vellykkede to Dages Besng i Ensted Sogn (20). 7.) samt Kongens aarlige Besug hernede, i Aar i Anledning af Aabenrua Havn og Hojspændingsværkets Indvielse, (H. 25. 5.) og senere igen midt i Juni, ved hvilken Lejlighed han overvarede Aahningen af Amtsudstillingen i Tonder. (H. 15. 6., Av. 16. 6.).

Et usædvanlig vellykket Stævne med 20i5 Deltagere fra alle Egne $\mathrm{i}$ Landet var $\mathrm{H}$ jemstavnskursusse t i Tonder i farste Uge af August. (H. 2. 8. ff., Av. 3. 8. ff.).

\section{Samfundsforhold.}

(herunder Moralog $\mathrm{H} \mathrm{y} \mathrm{gi} \mathrm{e} \mathrm{j} \mathrm{n} \mathrm{e).}$

Erhvervsfordelingen er endnu her i sonderjylland lidt sundere end $i$ det ovrige Land, for saa vidt som næsten Halvdelen af Befolkning (43\%) er sysselsat ved Landbrug. (Av. 8. 9.) Imidlertid laa denne Procent- 
sats $\mathrm{i} 18 \times 2$ omking ved (30), saa at den ogsaa her har vapet i stark Tilhagegang.

Ved Udst y k n i g kan denne Tilbagegang vel hammes en Del. Udstykningen sker baarle fra statens Side og ved Udstykningsforeninger. Fra 1922 til slutningen af 1924 har Udstykningsforeningen for Sinderjylland oprettet 19 Husmandshrug og venter at faa lige saa mange dannet i 1925 (H. 15. 1.). Paa Statens Foranstaltning udstykkedes 19:5 store Alealer (5\%9 ha) fix Olufskar, Fiskbak, Buskmose, Schackenborg og Ronhave (H. 24. 1.). Der dannedes derved over 70 nye Husmandshrug (H. 4., 5. 3., 8. 4.). I Hejsel byggedes der $\&$ nye Hjem, og der er Jor d til 5 mere (H. 9. og 13. (i.). Befolkningens Forstaaelse for denne Virksomheds Betydning er voksende (11. 5. 12.).

I Forbindelse med den staar vel den starkt voksende Sans for $\mathrm{K}$ olonihaver ved Byerne. Alene ved Haderslev er der $\mathrm{i}$ de senere Aar dannet flere Hundrede Kolonihaver. Samtidig er Antallet af Kolonihaver i Flensborg

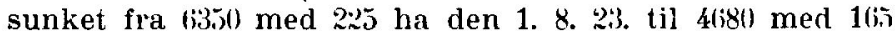
ha 1. 8. 25. (Av. 14. 11.).

Boligfor holdene i Byerne er endnu vanskelige, men bedres dog stadig. Fra 1. 10. 24. - 1. 10. 25. blev der opfort nye Lejligheder: i Haderslev 26 , Sınderborg $8($, Aabenraa 44, Tonder 16, I.rgumkloster 8 . Endvidere var der 1. 10. 25. under Opforelse: i Haderslev (i3, Aabenraa $\boldsymbol{T}$, Sonderborg 104, Tinder 8, Logumkloster 3 Lejligheder. I Sonderbory var der paa det Tidspunkt endnu planlagt yderligere 90 Lejligheder (H. 8. 12.). I Haderslev bygger 22 Familier paa Fjordager, 20 bag Kasernen (H. 27. 8.). I Skærbak byggedes der 1924 10 Huse, ligeledes 1925. (H. 12. 1.).

Morale n har desvarre vist svare Brist. Kionssygdomme er starkere udbredt end $i$ det ovrige Land. (Av. 1. 11.). I Haderslev afsloredes en vidt forgrenet Homoseksualisme (H. 2., 3., 9., 11. 11., 5., 21. 12.) og senere Fosterfordrivelse (II. 30. 11., 1. 12.). 
Til stor Skade er her den alt for lette .Adgang til A lkoholnydelse. Tunder Amt alene har 150 Bevarininger eller paa Landet 1 for hver 300, i Byelne 1 for hver 2411 Indbygrgere (Av. 2y. 5.). I Abild blev Kroen stemt ned den 24. 11\%, mens der samtidig var Flertal for, at Værten skulde have Bevilling. (H. 20. 10., Av. 20., 27. 10.).

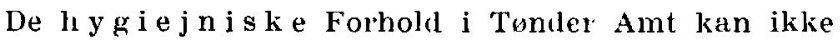
kaldes gode, om de end paa flere Punkter er bedret (Av. 3. (j., H.10. 6.).

For de s y g e er der gennem mange Aar gjort et godt Arhejue af Sygreplejeforeningerne. Den i Skærbak holdt 25 Aars Jubilæum d. 3. 2. og den i Brede Sogn Dagen derefter (H. 5. 2., Av. 6., 7. 2.). Plejestederne for syge og svage er i Vakst. Ved Vilstrup Strand har Sunderjydsk Fond indrettet et Welanderhjem (Ehlershjenmet) for Burn med medfudt syfilis. Det toges i Brug (1. 9. 5. (I. 11. 5.). Inval1deskolen i Sunderborg kan derimod afvikles (H. 15. 9.). Burnenes Helsehjem ved Vilstrup Strand har ved Indsamling faact $8614 \mathrm{Kr}$., men Burneantallet stiger stadig. (II. 11). ४.). sindssygeanstalten, der i Fjor indrettedes $i$ den ticligele Banegaard i Hviding, har 160) Patienter (Av. :22. 10.) Statshospitalet i Sonderhorg or for Jille (Av. 7 . 11.). Fabrikant Bach i Kobenhavn har stiftet et Legat pra 16,w0 Kr. til Bekwmpelse af Tuberkulosen 1 sinderjylland (H. 14. 11.). Amtssygehuset i Tunder hlev uãviolet ved en Tilbygning (H. 2. 11., 21. 12., Av. 3. 11., 19., 22. 1\%).

Centralforeningen af $\mathrm{Sygek}$ as e r i Sanderjyllan.l omfatter nu 105 Foreninger med 64,311 Medlemmer $0 g$ 1,32, $11(6)$ Kr. Bidrag. (H. 13. 20. 7.).

A lderdomsh jem forberedes i sunderborg (H. 30. 7., 5., (i. 8.) og Aabenraa (H. 31. 7.). Hjælpevirksomhed $i$ forskellig Retning udfoldes af df $n$ sonderjydske Kvindeforening, der har 4,484 Medlemmer, og hvis Regnskab balancerer med 2:,714 Kr. (II. 1, 7.).

De tyske sociale Forsikringer blev endelig 
afviklet, idet Nordslesvigs Andel i dem blev udhetalt til Danmark med 1,030,368 M.

De frivillige $B$ rand $\mathbf{v} æ \mathbf{r} \mathbf{n}$ Sonderjylland udgur ei Forbund af 30 Værn med 268 Medlemmer. Falk fandt 1 dem sine Redningstanker virkeliggjort. Sonderjylland har paa det Punkt et Forspring. Han beundrer, hvad han her har hort og set. De gensidige Brandforsikringer har bevilget Forbundet 4000 Kr. (H. 7. 8.).

\section{Erhverv og פkonomi.}

a) L a n d b r uget.

Vort bærende Erhverv er Landbruget. Dets Grundpille er selve Jorden. Dennes Behandling er der da ogsaa i dette Aar gjort meget for.

Paa flere Egne er der sat store M e rgling a r bejd e r i Gang. Haderslev Amtsbaner skaffede sig Ret til Udnyttelse af Mrrgellejer ved Arnum og Spandet og har udkart store Mængder (H. 6., 26. 1., 17. 4.). Fra Urnehoved udksres daglig 4-60)( $\mathrm{m}^{3}$ (H. 23. 7.). Neget er gjort i Aabenraa Amt siden Krigen (H. 16. 10.). Et nyt Foretagende sættes i Gang i den nordlige Del af dette Amt (H. 21. 10., 16., 21. 12., Av. 22. 10.). Statsgeolog Milthers siger, at Sunderjylland her Mergel nok til eget Brug (H. 17. 12.).

A f v a nd ing trænges mange Steder haardt til og drives stærkt. Det storste Foretagende er det ved Tonder, der i Aar endelig blev bragt saa vidt, at der ved Aarets Slutning kunde siges, at selve Arbejdet nu kunde sættes 1 Gang snarest muligt. (H. 27. 2., 7. 3., 28. 6., 22. 8., 22. 10., 6., :1. 11., 2., 5., 10., 18., 31. 12., Av. 9. 9., 11., 14., 17., 21. 10, 1 , 17., 20. 11., 2., 15. 12.). Et andet stort Foretagende paa denne Egn, nemlig Afvandingen af Sejersbæklavningen, opnaaedes der mod Aarets Slutning ogsaa Enighed om. (Av. 1., 16. 12.). Tiset-Kastrup Afvandingsselskab har afvandet 100)( ha for $44,879 \mathrm{Kr}$. Desuden har Hedeselskabet udført en Række mindre Afvandingsarbejder og Vandlubsreguleringer. (Av. 5. 7., 31. 10.) Professor Wesenberg-Lund fore- 
slaar at lade en af Aaerne ligge ureguleret. (Av. 3. 9.). Hvor stor Afvandingens Betydning er isar for Marsken synes at fremgaa af Forsag, ved hvilke Udbyttet paa Jord, der ellers var af omtrent samme Bonitet, kunde svinge mellem praktisk talt intet og $7500 \mathrm{~kg} \mathrm{H} w$ pr. ha (Lbr. S. 453).

God Oplysning paa Planteavlens Omraade gav invrigt en Udstilling, som Aabenraa Amts Landboforening lod afholde (H. 14. 10.).

$\mathrm{Sk}$ ovbruget var indtil Genforeningen temmelig forsomt. For 3-4 Aar siden blev der nu dannet en Smaaskovsforening i Aabenraa og Sonderborg Amter. Den har nu 172 Medlemmer med henved 1000 ha Skov (H. 16. .). Samtidig har Plantningsselskabet "Sonderjylland" siden Genforeningen tilplantet 28,25 ha Klit og Hede, i $24-25$ 5,7 ha. (H. 9. 6.).

Forholdsvis ny er Sukkerroedyrkning. Dog er der siden Genforeningen bleven dyrket storre Arealer baade paa Als og Haderslevegnen. I 1925 blev der Tale om at bygge en Saftstation i Haderslev (H. 10. 3., 18. 4., 4. 5.). Det blev dog ikke til noget.

Paa Vestkysten fortsættes Dige by $\mathbf{g} \mathbf{n}$ ingen. Den 28. 4. afleveredes Diget ved Rejsby. Imidlertid forberedtes 2 Diger paa Rømø (Av. 31. 1., 29. 7., H. 10. 9., 19. 10., 7. 11.). Digerne er overalt bleven forhøjede $i$ de senere Aar og maa nu være høje nok. (H. 20. 11.).

Jordfordelingen er der bleven gjort en Del for at forbedre. Det lykkedes den $i$ det Øjemed nedsatte Kommission at faa magelagt 700 ha $i$ det forste Aar (Av. 28. 7.).

H w s t e n lovede godt (H. 12. 6.). Paa Skærbæk Enge var der imidlertid slemt Larveangreb (H. 22. 6.). Kornhısten blev dog ikke saa stor som ventet (H. 18., 21. 8.). De faldende Kornpriser bragte Tab. Storst blev Tabet dor for Grasserne, maaske 5 Millioner $\mathrm{Kr}$. atene i Tunder Imt (Av, 18., 21. 11., H. 24. 11.). 
K v $æ$ g a v l e $n$ kan notere betydelige Fremskridt. Navnlig er Forstaae!sen for Kontrolforeningernes Betydning vokset stærkt. Ved Nytaar 25 var 30,060 af Landsdelens 96,000) Kier (32 \%) under Kontrol (Lbr. S. 11). Stnderhorg og Hadersiev Amter stod allerede ved Slutningen af $19: 24$ procentvis med de storste Antal kontrollerede kner i Jylland, og Aahenraa Amt fulgte godt med (H. 19. 2.). Farlleslandboforeningen meddeler, at der er bí Kontrolforeninger. Af dem havde 59 med 143:3 Besatningrel, omfaitende 21,766 Kuer, Aarsopgorelse. Smarydelsen var 10,1 $\mathrm{kg}$ storre end 1923, men der var lidt Tilbagegang for svinene (H. 26. 2., 19. 3., 20., 24. 10., 3. 11., 10. 12., L.br. S. 191, 19:, $8: 2(1)$. Fallesledelsen af Avl af rodt dansk Malkekvag har 220 Medlemmer med 25if Kuer. Der er aarlig Fremgang indenfor den (Lb)r. S. 15)().

skınt der i Sunderjylland er mange svineslagte r i e r, er der ogsaa i Aar kommen flere nye til, saaledes i Rudding (H. 10., 12. 9., 20. 11.), og Vojens (H. 8. 10.). De synes dog at gat godt (II. 23. 2., 27. 3., 21. 12., Av. 2't. 2\%. Der er desuden taget Beslutning om at oprette et Aktiesvineslagteri i Tonder (Av. 5. 4., H. 4. 4.) og bygge et nyt i Aabenraa (H. 1. 4., 30. 6., 13. 8.). Sinderlorg Andelsslugteri tyngedes $\log$ af for stor en Anlagsgexlit ogr maatte nedskrive den med 4h(0,000) hr. (II. 24. 10., Av. 25. 10.).

Stor Skade voldte Mund- og K lovesygen. Ved Aarets Begyndelse havde der saaledes i Haderslev Amt været angrebet $\$ 5$ Besatninger (H. 21. 1., 21. 3.). Upraktiske ministerielle Bestemmelser gjorde ikke Tabene mindre, men voldte derimod stor Ctilfredshed og matte tages tilbage. (H. 18., 20., 22., 24., 22. 6., 1., 10., 11., 16., 21. т).

M e jeribruget er i god Udvikling. Mejerierne her er saa starkt inde paa Afregning efter Fedtprocent, at den ved Aarets Begyndelse hrugtes paa bi) pC.t. af dem, mens i hele Danmark kun $23 \%$ bruger den. I Februar var der allerede $80 \%$ (Lbr. S. 1(i7). Ligeledes er de sin- 
lerjydske Mejerier foran med holeanlag $(95 \% \bmod 67 \%$ for hele Landet) og med Mrelkebedommelse $(84 \% \bmod$ (99). Men Mejerierne er for smaa og Marlken for mager. (H. 10. 2., 14. 3., 20. (6., 3. 9., 4. 12., Lhr. S. 11, 187, 2(1). Imidlertid er Malkemængden her vokset med 9,5\% mod 4,4 \% i hele Landet, og ogsaa gaat frem i hvalitet. (H. 3. 9., Lbr. s. 4ti, 14ti, 187, 204, 2:38, 301:2, 411, 51), 813).

Smorhandelen foregaar jo for en stor Del gennem Smoreksportforeningtrne. Den i Tonder solgte $509,6010 \mathrm{~kg}$. dens Indtagt var $2,734, \times 28 \mathrm{Kr}$. i $19: 4$. (Av. 11. 1.). Sinderjydsk Smmreksportforening (i Vojens) solgte for 11/2 Million Kr. (i4 $\%$ af det gik til Tyskland. (H. 31. 1.). Den i Sonderborg har forhandlet 35,943 Dritler. (H. 21. 12.). Haderslev Smoreksportforening omsatte 13,000 Foustager Smor til en Vardi af 3,000,000 Kroner. En Række Mejeriers Indtagt ved Smorsalg angives. (Av. 25. 9.).

Ogsaa i Aar er enkelte Mejerier bleven udvidet eller ommonteret, saaledes "Klıvergaard" i Fasted (H. 18. 11.). Pal Mejeri holdt 60 Aars Jubilaum. Det begyndte som Fællesmejeri (H. 7. 9.). Mod Slutningen af Aaret fortes der Forhandling med Mejerierne om at sætte Mælketorreriet i Haderslev i Gang. (Lbr. Ti(i)).

Med Tilfredshed har Landmandene set Ejerne af Rakkerierne i Bro, Sdr. Hostrup og Hammelev miste Eneretten til at modtage og behandle selvdode Dyr (H. 22. 12.).

Ogsaa Oprettelsen af en B es lags k o le i Forbindelse med Landbrugsskolen ved (iraasten er bleven hilst med Giæde (Lbr. S. (694).

Aabenraa Amts Landboforening oprettede 19:2 en Regnskabs f orening, der omfatter 37 Landbrug. Regnskaberne for 19:2--25 viste, at Udbytteresultatet var ret godt. Den bogfurte Landbrugskapital var $2248 \mathrm{Kr}$. pr. ha, deraf var 1432 , altsaa $64 \%$ fremmed Kapital. Græsarealerne lonner s:g ikke. Det er Kuer, Korn og Svin, der har givet Udhyttet. (H. 5. 12., Landbrugsregnskaber for 
Aabenraa Amts Landboforening 1924/25). Ogsaa for 2223 og 23/24 foreligger Regnskaberne trykt. Af saadanne Regnskabsforeninger fandtes 5 , nemlig 2 paa Als, 1 i Sundeved, 1 paa Roddingegnen og den oven omtalte. (Meddelt af Regnskabskonsulent Frederiksen i Aabenraa).

En ny L a n d b o f ore $n$ ing dannedes for Tinglev og Omegn med 80 Medlemmer (H. 23. 10.). Fælleslandboforeningen har nu 4,548 Medlemmer, men har haft 6000. Landbrugs- og Mejeritidende" har 2050 Holdere, 300 flere end ved Nytaar 24. (H. 25., 20. 2., Lbr. S. 146).

Faglig Oplysning er foruden gennem Foredrag, Forseg, Markvandringer o. 1. spredt gennem Landbrugskursus forskellige Steder. (H. 16., 17., 26. 1., 3. 2.). Noget nyt var et Vandrekursus i Rens, Bylderup, Rabsted og Terkelsbøl (H. 17. 10., 2., 9., 18., 25. 11.) og et Ungdomsmode i den nordslesvigske Landboforening (H. 27. 10.).

Ejendomsskylden blev mange Steder sat op, gennemsnitlig $10 \%$ navnlig i Sønderborg Amt og den østlige Del af Haderslev Amt (H. 9., 13. 3.).

De sønderjydske $\mathrm{H}$ u $\mathrm{s} \mathrm{m} æ \mathrm{n}$ d holdt Sendemandsmode i Haderslev 6. og 7. 6. (H. 8. (6.). 8 sønderjydske Husmand fik Sølvmedaljen fra de jydske Landboforeninger (H. 14. 10.).

En Oversigt over Landbrugsforhold i Sonderjylland i 1925 (Lbr. S. 817).

b) Industri og Haandvær k.

Dette Kapitel fylder ikke stort i Aarets Historie.

Udstillingerne er dem, der mest har, vakt Pressens og dermed Almenhedens Opmærksomhed. Af der har der været ikke saa faa. Den betydeligste var Amtsudstillingen i Tonder, hvor der navnlig var meget godt Haandværkerarbejde udstillet (H. 14., 15., 19., 20. 6., Av. 16., 17., 18., 19., 23., 24. 6., 3. 9.). Andre Udstillinger fandt Sted i Løgumkloster (H. 9. 3.), Skærbæk (Av. 24. 2.), Højer (Av. 5. 3.), Tinglev (H. 2. 10.) og Graasten (II. 15.-22. 11.). Maler- 
mester A. P. Sorensen i Rodding fortæller orn Udstillingernes Historie gennem Aarene (H. 27. 8.). En gammel Virksomhed le vede op i ge $n$, idet Kalksanästensfabrikken i Mrgeltønder blev sat i Drift paany. (Av. 23. 1.). Fra ældre Virksomheder meddeles, at Savværket it ansborgs Omsætning var 551,235 hr. (H. 13. 3.). C i m b r a i Aabenraa har hafi et Underskud af 48,193 kr. Der tegnedes ny hapital og valgtes en ny Bestyrelse (H. 2(i. 3.). Aktiebryggeriet $\mathrm{i}$ Tonder havde en Del storre Omsatning end Aaret for, og Overskuddet blev rigelig $26,000 \mathrm{Kr}$. (Av. 31. 3.). I sinderborg indviedes en ny tekn is k Skole (H. 14. 9.).

c) Handelog Skibsfart.

Handel og Skibsfart fylder mere op i sunderjyllands Erhvervshistorie.

Den n y $\mathrm{Havn}$ i A a be $\mathrm{n}$ a a blev indviet, samtidig

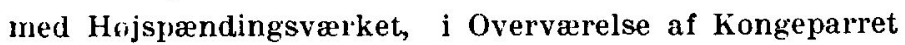
Lien 23. 5. (H. 22., 23., 25. 5., Av. 23., 24., 26. 5.). Dens officielle Lybde er $6,5-\tau, 5 \mathrm{~m}$ (H. 25. 11.). Baade $\mathrm{i}$ den og de andre Havne er der livlig Tratik. Sønderborgs Forventninger til sin Havn er gaaet i Opfyldelse (H. 2\%. 1.). Graasten har med sine $155 \mathrm{~m}$ haj overordentlig livlig Trafik (H. 24. 8., 14. 10.) ikke mindst ved Udforsel af levende hreaturer ( $H$. 19. 9.). Hadersiev Havn, hvis Udvidelse kostede 1,321,413 lir., havde i $24 / 25$ i Bro- og Havnepenge en Indiægt af 16i4,5̆ti8 Kr. (H. 6. 8.). Ogsaa paa Højer's lille Havn vokser Trafikken, efter at Sejlrenden er bleven uddybet til $2 \mathrm{~m}$. For forste Gang efter 40 Aar's Forløb indkom her et Skib med Trælast (Av. 31. 7.). En Statistik over Benyttelsen af de sunderjydsize Havne viser, at Senderborg har det storste Antal Skibe og Tons, henholdsvis 990 og 66.457 (H. 22. 12.). I Norborg droftes Anlagget af en Havn ved Dyvig (H. 5. 11.). Aabenraas Handelsflaade for 75 Aar siden (H. 11. 16.).

Den voksende Trafik har krævet nye $\mathrm{Pakh}$ use. Ved Aabenraa Havn har Math. Nielsen rejst et Silopakhus ( $H$. ४., 29. 1.). Ligeledes ved Haderslev Havn (H. 10., 12. 1.). 
Ligeledes har den nodvendiggjort ny og moderne I. o sseindretninger. En saadan har Math. Nielsen bygget ved sit Silópakhus i Aabenraa (H. 8. og 29. 1.). I Haderslev nægtede Havneudvalget ham derimod Lov til at opstille en lignende (H. 30. 3.). Kulkraner byggedes ved Haderslev og Aabenraa Havne (H. 1. 7., 13. 8.).

I Sanderborg skal der bygges en ny $\mathrm{T}$ o $1 \mathrm{~d}$ bo $\mathrm{d}$.

Af $\mathrm{H}$ a ndelsselskaberne nedsatte Sonderjydsk Kompagni sin Kapital til 11/2 Million, da den var for sto: til dets nuværende Omfang (H. 21. 7.). I Haderslev dannedes der et Kul- og Koksimportselskab (H. 8. 8.). I) san.virkende sønderjydske Brugsforeninger, der længe har va ret i Likvidation, har ca. 190,000 $\mathrm{Kr}$. Underskud. Der anlægges nu Sag mod Medlemmerne (H. 4. 11.).

Skibenes Fortjeneste har været ret forskellig. Ahrenkiel \& Clausens "Alpha" og "Delta" har tjent godt. "Delta" giver $25 \%$ i Udbytte (H. 7. 1.). Aabenraa Rheder1 har tjent $22 \%$. Det udbetaler $10 \%$ Dividende. (H. 9. 3.). Derimod har de forenede sønderborg-flenshorgske Dampskibsselskaber et Underskud af $135,(190 \mathrm{Kr}$., hvoraf $48,0 \mathrm{0}, 0$ falder paa det smnderborgske (H. 14., 31. 3.).

Den nye Skibstype Rotorskibet, gastede flere Gange især Flensboing Havn (Av. 10. 1., 11., 13. 2., 3. 9.).

I Aabenraa indrettes den tidligere Navigationsskole til en Kystskipperskole (H. 16. 11.).

d) Pengeforhold.

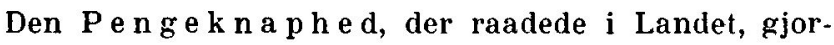
de sig særlig stærkt gældende her i Sonderjylland, navnlig da Kronen steg saa stærkt. En medvirkende Grund til den var her, at saa mange Kreditforeningsobligationer, formentlig 30 Millioner, laa belaant i Pengeinstitutterne. (H. 26. 1.). Den mærkedes særlig haardt i Landbruget, og Trykket af den ogedes stadig. Mod Slutningen af Aaret krævede Den nordslesvigske Landboforening derfor snarlig Hjælp til Bedring af de vanskelige Kreditforhold. (H. 7. 12.). 
Da Afsætningen af $O b l i g a t$ i on erne maatte være af Vigtighed, forhandledes der allerede i Marts om Statsstutte i dette Ojemed (H. 16. 3.) og 4. 4. vedtoges i Folketinget en Lov om $\mathrm{Stats} g a \mathrm{rant}$ for en ny Serie af Sonderjyllands Kreditforenings Obligationer. Den 7. 4. vedtog Landstinget den mod de konservatives og Kloppenborg Skrumsagers Stemmer. (H. 6., 8., 11, 4.). Denne 3. serie noteredes forste Gang 3. 7 . og stod da $\mathrm{i} \times(0) \frac{1}{4}, 1 / 2$ Points hojere end 1. og 2 højere end 2. Serie. (H. 4. 7.) snait ogsaa lojere end flere andre Kreditforeningers (H. 24. 7.). For Resten viste en Sammenstilling af Kurserne fra 1. 1. 20.-1. 7. 25., at Sonderjyllands Kreditforening var i Fremgang og nu ikke stod daarligere end Vest- og sønderjydsk hreditforening. (H. 10. 7.) Dens samlede Udlaan udgar 120 Millioner i 5,7xi Laan (H. 9., 23., 26. 10.). 31. 3. var der 105,9 Millioner. Vest- og sunderjydsk Kreditforening havde 33,5 Millioner i Sunderjylland og Jydsk Husmandskreditforening 20(1), Mill. (Realkreditkommissionens Betwnkning s. 87. (Sml. HI. 12. (6.).

lange mente, at en væsentiig Del af Grunden til Pengevanskelighederne laa $i$, at Sunderjyllands Kreditforening havde faaet Eneret til at virke 1 Storstedelen af Sonderjyiland og rejste en haftig Kamp mod de $n$, netop da Stotteaktionen stod paa. ( $\Lambda$ v. 9., 10., 15., 16., 17., 26., 27., 31. 5., 4., 5., 7., 17. 16. H. 12., 23., 30. 5., 4. (i.). Landmand paa Als og Sundeved samlede endog Underskrifter paa et Andragende til Regering og Rigsclag om Ophavelse af dens Eneret (Av. 5. 7.).

De vanskelige l'engeforhold har vel haft deres Del i, at Aaret blev serlig rigt paa Planer om og til Dels Oprettelse af nye Pengeinstitutter. Paa f̣lere Husmandsmoder droftedes satedes oprettelsen af Husmandslaanekusser (H. 23., 25. (5., 3. 7.) og i Tinglev oprettedes en Driftslaaneforening.

En Sagforer Nielsen i Kolding, bekendt fra Valutaspekulationer i Overgangstiden, gav Studet til Droftelsen at 
en Plan om en Hypotekkasse. (H. 14.. 23. 3.), der skulde skaffe sig Penge fra Amerika (H. 3. (i., Av. 8. 7.). 29. 8. oprettedes "Slesvigske Bonders Hypotekkasse". Flere Garanter krævede sig slettet. (H. 31. 8., 2., 8. 9., Av. 1. 9.) og den fik ikke Lov til at virke som Kreditforening (H. 22.). 11.). Enkelte mistede under Arbejdet mod de okonomiske Vanskeligheder rent Herredommet over sig selv. Gaardejer Kylling i Frorup truede i "Apenrader Tageblatt" - efter at alle clanske Blade havde lukket deres Spalter for ham Regering og Nationalbank med, at der vilde sske noget her nede«, hvis de ikke standsede Kronens Opgang og forte den tilbage til 50-60. (H. 31. 7.). Nogle Dage senere talte han paa et Mode i Bolderslev sammen med en Tysker, der ogsaa var utilfreds. (H. 10. 8.). Ogsaa Cornelius Peter'sen begyndte nu at rakke ned paa alt dansk. (Av. $25 ., 28 ., 29.9 .$, 4. 10. H. 28. 9., 3. 10.).

Nogen Lettelse af Stillingen gav det, da Nationa!banken nedsatte $\mathrm{D}$ is k o $\mathrm{t}$ o e $\mathrm{n}$ forst fra 7 til 6 , (H. 25. 8.), og derefter til 51/2. (H. 8. 9.). Spar'ekasserne gjorde Skridt til almindelig $\mathrm{Ned}$ sæ $\mathrm{t}$ e ls e a f Renten, (H. 12. 9.), uden at det dog straks forte til noget. Resultat undtagen delvis i Sonderhorg Amt. (H. 7. 9.).

Af Betydning for mange blev det, at den sonderjydske La a nekase genoprettedes med en Kajital paa 2 Millioner Kr. (H. 13., 31. 1.) til Ldlaan til Crundlaggelse af selvstændigt Erhverv eller Erluvervelse af fast Ejendom og $3 / 4$ Millioner til Udlaan til Invalider. (11. ..., 20., 27. 2.). Den traadte i Virksomhed 1. 4. (H. 31. 3.). Der indkom hurtigt ca. 3000 Andragender om Laan (H. 16. 4., 9. 7.). hvoraf 1(4) hevilgedes. (H. 18. 7.).

For ret at faa taget alrorligt fat paa Ondet og faa fundet Midler til at raade Bod paa det med, nedsatte Regeringen 16. $\%$. en Kommission til Undersagelse af Realkreditforholdene paa I.andet i Sonderjylland. (H. ㅇ․ 7., 13. 10., 23. 10.). Den naaede ikke til Ende med sit Althejde for Aarets L'dlnb, men dens Betankning, der hler afgiret og 
foreligger trykt (Betænkning afgiven af den sonderjydske Realkredikommission, 192(i) kaster skarpt Lys over Forholdene, som de forelaa i $1925 \mathrm{og}$ over de foregaannde Aars skonomiske Udvikling.

Imidlertid var Inds k u d ene i s parekasserne og B a n k e rn e allerede begyndt at vokse (H. 17. 1., 22. 6. 2. 7., 4. 7., 23. 9., 25. 9. Av. 6. 3.) og B anke rne, der ikke saaledes som Sparekasserne havde lidt af Mangel paa Midler kunde se tilbage paa on tilfredsstillende Virkeperiocle og udbetale meget gode Dividender. (H. 5., 6.. 16., 28. 2., 4., 19. 3.). Enkelte af dem fik dog som Falge af forkerte Dispositioner Vanskeligheder at kæmpe med. Saaledes Folkebanken for Als og sundeved, der dog overvandt dem ved, at Befolkningen stillede den fornndne Sum, 400,000 Kr., til Raadighed i Form af nye Aktier. (H. 24. 10, 4., 14. 12.). Ligeledes havde Landmandsbanken i Tonder faaet et Underskud paa $300,000 \mathrm{Kr}$., der ogsaa dækkedes ved Tegning af nye Aktier, (Av. 20. 12. H. 21. 12.) og Nordslesvigsk Bank matte afskrive $3(0),(M) \mathrm{Kr}$. som Tab, hvorimod der tegnedes 200,0(n) Kr. ny Aktiekapital. (H. 30., 31. 12.).

Haderslev Bank fejrede 16. 10. sit 50 Aars Jubilæum, (H. 16. 10.), i hvilken Anledning Bestyrelsen udgav Bankens Historie (Haderslev Bank 1875-1925), der bringer megen vardifuld Oplysning om det okonomiske Liv i Nordslesvig i dette Tidsrum.

De kommunale Sparekasser fik Fristen for deres Omdannelse i Overensstemmelse merl den danske Sparekasselov forlænget til 1983. (II. 21. 12.).

Sønderjydsk Mejeriforening opfordrede Mejerierne til at stotte Andels a nken i dens Vanskeligheder ved at tegne $2 \mathrm{Kr}$. for hvert 1001) kg Mrlk leveret i 19:24. (H. 23. 5.). Inden det skete, standsede Banken imidlertid sine Betalinger. Den harde 1:2 Mill. Kroner anbragt her nede. (H. 2. 6.). 
Sonderjydsk Fond har i 1924 ydet Hjælp til et Belnb af $547,333 \mathrm{Kr}$. saavel Syd som Nord for Grænsen. (H. 23. 3.).

Den i Tyskland forestaaende opskrivning af $\mathbf{M ~ a ~ r ~ k - ~}$ tilgode havende fik mange til at anmelde Krav hos Sparekasserne, der dog ikke kunde tage imod dem. (H. 25. 3.).

e) $\mathrm{Sam} \mathrm{k}$ ve $\mathrm{m}$.

I deles Kamp for at havde sig mod Biltrafikken har A $\mathrm{m} \mathrm{s}$ hanerne for lange siden maattet ty til Anskaffelsen af Motorvogne, fırst i Haderslev Amt. Ogsaa de alsiske Baner gaar nu over til det og satte den 4. 4. de forste Mortorvogne i Gang. (H. 31. 3.). Alligevel kæmper de fleste af disse Baner med store Underskud. I Haderslev Amt er det dog nu nede paa $100,000 \mathrm{Kr}$. (H. 9. 6., 31. 8.), i Sonderborg Amt paa 101,(00, men saa skal der nu lagges ny Skinner til et Belkb af 575,000 Kr. (H. 17. 9., 22. 10., 16. 11.). I Aabenraa Amt viste det sig, at Underskuddet, der var anslaaet til 60,004) Kr. vilde blive 150,000. Der blev Banerne derfor nedlagt. (H. 3. 10., 18. 11., 30. 11.).

Statsbanerne derimod indforte ogsaa $i$ Aar væsentlige Forbedringer i Koreplanen (H. 1. 5., 7. 5.) og traf Forberedelser til ny Udvidelser af Driften. Der blev eksproprieret Jord til Banen Rodekro-Logumkloster (H. 17. 12.) og gjort Forarbejder til Broen over Alssund, (H. 25. 4., 20., 21. 8., 3. 9., 12. 10., 12. 11.) samt lagt Plan og truffet Forheredelser til en eventuel Flytning af Banegaarden i Aabenraa. (H. 18. 2., 10. 3., 5. 8.).

Imidlertid vokser Vejf $\mathrm{dr}$ d l en starkt, i Sonclerborg og Aabenraa Amter med 60 pCt. fra 19:2 til :4. (H. 17. 3., 16. $\operatorname{og} 23$. 4.). Beslutningen om at nedlagge Aabenraa Amtsbaner førte da ogsaa straks til Dannelsen af et Rutebilselskab med $75,(0(0)$ Kr. Kapital. (H. 9., 15. 12.). Den stærke Vækst af Vejfærdslen nodvendiggor store og dyre Vejbygningsarbejder. (H. 2. 6., 6. 11.). 
Antallet af Telefonabonnenter pr. 100\% er nu ligesaa stort som i Norrejylland og Antallet af Samtaler pr. Abonnent storre, (H. 1., 21. 10.), nemlig 1559.

Den tyske Dæmning til sild lukkedes den 10. 9. (H. 22. 9. Av. 5. 12.), men er alligevel langt fra færdig endnu. Den vil koste 10 Mill. M. (H. 24. 10.)

\section{Kommunale Forhold.}

Haderslev, Aabenraa, Sınderborg, Tonder, Augustenborg, Logumkloster og Hojer er nu udtraadt af Fællesskabet med Amtskommunerne. Norborg bliver indtil videre under Sonderborg og Christiansfeld indtil 1931 under Haderslev Amt. (II. 23. 5.).

Byerne er alle i god U d vikling (se under $2 \mathrm{~d}$ og 4). Tinder har siden Genforeningen ofret 2,773,150 Kr. paa sin videre Udvikling. (Av. 4. 3.). En historisk Oversigt giver Bagermester Thy. Petersen. (Av. \&. 11. ff. sluttet 4. 12.). Den er ret relstillet, idet den har 450 ha Legatjord til $910,000(1$ Kr., der i 1924 gav 120,000 Kr. Indtugt. (Av. 27. 2., 6. 11.).

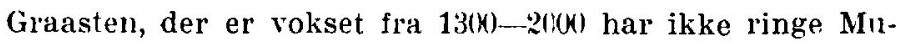
ligheder. (H. 18. 4.). Flere Steder blev der anlagt nye Gader, saaledes i Haderslev (H. 27. 8.) og i Sonderborg. (H. 9. 1.).

Væksten kræver Udvidelse og Nyanlæg af ko m mun a l e V arker. (H. 28. 1., 27. 7., 1. 4., 26. 6., 12. 9.). Det mest storstilede kommunale eller rettere landskommunale V'ark er Elektrificeringen, der udfores af baade Hojspandingsvarket $\mathrm{g}$ de eksisterende mindre Værker. (H. 14. 1., 5. 3., 1. 4., 27. 4., 23. 5., 11. 6., 6. 7., 11. 8., 11. 12. Av. 30. 1., 2. 4., 15. 10.).

Under den raske Udvikling har der maattet gores (iæald, (H. 11. 1., 4. 11. Av. 11. 1.) og Skat terne i Byerne er bleven hoje. I Haderslev maatte Skatteprocenten endog forhujes fra 10,5 til 12,2, skont den skattepligtige Indtægt var steget med omtrent 1 Million. (H. 8. 1., 3. 2.. 
10. 2., 17. 3., 24. 3., 3. 4. Av. 15. 2. sml. H. 28. 9., 2. 10., 2(; 11.).

En Del af Aaret satte de $\mathrm{kommunale} \mathrm{Valg}$ en hel Del Rore. (H. 3. 2., 6., 7., 9., 10., 12., 16. 3. Av. 17. 3.)

\section{Kirkelige Forhold.}

Det, der paa Kirkens Omiaade voldte mest Røre, var noget saa udvortes som Planen om Udstykning af Pras t e ga arden e, (H. 10., 21., 24., 29., 31. 1., 3., 5., 20., 24., 28. 2., 5., 6., 2(6., 27. 3., 2., 8. 4., 30. 5., 10. 7.).

Haderslev Prorstis falles $\mathrm{K}$ irkekasse blev ophavet. (II. 8. 8.).

Den sturste Begivenhed var ellers Indrielsen af den nye Kirke i Vojens. (H. 4., 7., 8. 9.).

Nogle Kirker fik endnu ()rgelpiber skænket af Sunderjydsk Fond. (H. 2. 3.). Ialt er 38 Orgler bleven sat $i$ stand for 13:26; $\mathrm{kr}$.

Ansattelsen af kvindelige Præster udtalte de fleste Menighedsraad sig imod. (H. 12. 1.) Ved den danske Menighed i Sonderborg blev der ansat en 2. Præst. (H. 20. 10.).

Den gennemsete $\mathrm{Salm}$ e bog blev avtoriseret og vil snart blive indfurt. (H. 19. 12.).

Den 1. 3. viede Frimenighedsprost Niels Dael fra JIove Hojskoleforstander Aage Moller i Ronshoved til Præst for en Frimenighed der paa Egnen, der dog ikke vil stilles i lixkke med de andre sonderjydske Frimenigheder. (H. 4., 6. 3. Av. 3. 3.).

Den 13. 9. holdt Haderslev Frimenighed 25 Aar Fest for Indvielsen af sin Kirke. (11. 9. 1900). (H. 12., 14. 9.).

\section{Oplysning.}

I B e retninger, Amtsskoledirektionerne i Aabenraa, Sonderhorg og Tonder Amter udsendte, gjordes der Thede for skolevasenets Udvikling i Aarene 1921-24, bl. a. 
ogsaa om Burneantallet $\mathrm{i}$ danske og tyske Klasser. (H. 29. 9. Av. 30. 9., H. 20. 1., 4. 5., Av. 2. 3.).

I Hoptrup blev s k ol e n udvidet. (H. 4. 9.). I Sxd krarvede 62 Underskrivere med 31 Burn en dansk skole eller en Centralskole. (Av. 1. 11.). 2. Paaskedag indviedes en ny Realskole i Tinglev, (H. 11., 14. 4. Av. 15. 4.), Mjols fik en ny Skole. (II. 15. 11).). I I tge opstod en Konflikt mellem Kummuneskolen og den ty:ke Privatskole, som det dog lykkedes Prasten at faa lilagt. (II. 11. 11.).

Undervisningsministeren had om ikke i saa udstlakt Grad at indstille unge $V$ ikarer til fast Ansattelse. (H. 5. 5.).

Der var lidt Nedgang i Antallet af Ansıgninger om Hjwlp til Besøg paa Hojskoler og Efterskoler, haade fra Nord og syd for (iransen. (H. 2. 9.). Rens Efterskole havde 19:4-2.) 44 Elever. Den fortsætter (H. 24. 8.) og faнr Randløv-Jensen til Forstander. (II. 2., 31. 10., 10. 11.). I Roduling opsagde E. Appel sin stilling som Forstancler. (H. 10. 11.). Redaktor sivensson fremsarter Planen om en konservativ Højskole. (H. 9., 10., 11. 11.).

Nye Forsamlingshuse ller bygget ng taget $i$ Brug i Kollund (II. 23. 2., Av. 29., 24. 2.) og II 10., Av. 6. 10.).

Bibliotekerne har ræret i god Cdvikling og hliver godt brugt. (H. 4. 2., 27. 4., 9., 12. 5., 4. 6., 31. 8., 26. 10., Av. 1 1\%, $\tau$.).

Grundene for og imod et Universitet i Sonderjylland offentliggores. (H. 10. 10.).

\section{Retsvasen.}

Justit.minister:an helouder Bevarelse og Udvidelse af Sondre Landsret. (H. t., 7. 11.). Derimod hliver Dommerfuldmagtigenes Virksombed en Del indskranket. (H. 29. 6./. 
I Sagen om de $\mathrm{h}$ emmelige $\mathrm{L}$ is te $\mathrm{r}$ under Krigen blev Redaktur Andr. Grau frifunden. (H. 5. 1., 17., 20. 2., Av. 18., 26. ?..).

\section{Personlige Forhold.}

Af F a d sels dage i 1925 skal næunes: 25. 3. blev J. Kloppenborg 90 Aar, (H. 24. 3.), 28. 3. Pastor v. Brincken (tidl. i Spandet) 80 Aar, (H. 27. 3.), 30. 3. Pastor Prahl i Gl. Haderslev 80) Aar, (H. 28. 3. ff.).

Af $D$ ø $\mathrm{d}$ f a $1 \mathrm{~d}$ nævnes P. Chr. Iversen i Avnbul 11. 1. (H. 12. 1.), Molleejer N. P. Boysen, Haderslev 28. 1. (H. 28.1.), Charitas Bischoff (H. 7. 3.), Chr. Michaelsen, Kastvraa 18. 3. (H. 19.3.), Jac. Kloppenborg paa sin 90. Fodselsdag 25. 3. (H. 26. 3.), Christian Høyer, Osterlindet (H. 31. 3.), Lektor ('udme, Aabenraa 15. 5. (H. 16. 5.), Jørgen Gundesen, Bristrup 27. 7. (H. 28. 7.), Postmester Nielsen, Haderslev 16. 8. (H. 17. 8.), Fhv. Hajskoleforstander P. Andresen, „Bredbjærg«« 15. 9. (H. 15. 9.), Direktır H. Magnussen, Hader'slev 1. 10. (H. 2. 10.), Seminarieforstander H. Skat Rørdam, Haderslev 5. 10. (H. 5. 10.), Pastor Andersen, Holebul (H. 15. 10.), Hans Hansen, Nejs (H. 17. 10.), Joh. Iversen, Ullerup (H. 29. 11.), Iver Kjems Gad, I.undsmark (H. 11. 12., Fisker P. Jensen, Egernsund आ. 12. (1. 31. 12.)

10. 5. fejrede P. Lassen i Strukstrup sit Diam a n tbryllup. (Av. 12. 5.).

26. 2. Generalsuperintendent Petersen (tidl. Provst i Haderslev) sigte og fik sin Afske(l. (H. 26. 2.).

H. Fuglsang Damgaard blev ułnæunt til D o c e n t red Universitetet. (H. 1. 7.).

26. 5. holdt den nordslesvigske $L$ a $n$ d b of o l e n ing 25) Aar's Juhilwum for Forpagter Jens IIwyer, Billeslund som Formand. (H. 27. 5.).

Skrave Mejeri holdt 30 Aars Jubilaum for Th. Frosch som Bestyrer (II. 7. 11.). 
5. 6. afsloredes en Mindesten for P. Skau paa hans 1011) Aars Fndselsdag (H. 4., 6. 6.).

\section{Andre Sager.}

En Række spredte Sager, der ikke let kunde henfores under de foregaaende Titler, skal endnu nævnes.

D y b b o l er bleven fredet (H. 28. 1., 9. 7.). I Touder

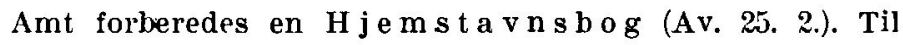
$\mathrm{Nat}$ ionalmuseumsfondet foretoges ogsaa her en Indsamling (H. 7. 4., 9. 6., 8., 10. 7., 22. 8., 8., 7., 28. 10., Av. 20. 11.).

Oldtidsf und omtales: Nydam (H. 14., 15. 5.), Nørborg (H. 11. 7., 25. 7.), Stepping Sogn (H. 27. 7.), en Bardehval ved Gram (H. 19. 9.), Udgravning i Logumkloster (H. 21. 10.), et Menneskehoved ved Dæmningen til Sild (Av. 5. 12.).

Hajskolehjemmet i Haderslev flk en Strimmel J o r d ved Dammen overladt (H. 13. 6.).

Kaptajn Fischer gav Stødet til en Indsamling af Materiale til A a benras Historie (H. 23. 6., 13. 10., 14. 11., 24. 11.).

Ved Rejsbydiget afsløredes en Mindesten for Ulykken i 1923 (H. 29. 6.). H e j ren trues med Udryddelse. (H. 2. 7.). Flensborgs Vakst fra 1813-1925 (Av. 9. 7.). Sy d Tønder Kredses Folkeantal (Av. 12. 7.). Historisk Samfund for Als og Sundeved har 102 Medlemmer (H. 10. 7.). I Haderslev laver Turistforeningen en stor Ildfest (H. 20. 7.). Sønderborg M u se um udvides (H. 28. 8.). L a k olk salges (28. 8.). E e m have ts Alder fastslaas ved Boring ved Tønder (Av. 19. 9.). Paa Tinglev Kirkegaard afsløres 19. 9. et $\mathrm{M}$ indes $\mathrm{m} æ \mathrm{rke}$ f o r K rigs f a nger (H. 21. 9., Av. 20. 9.). Om Sønderjyllands $\mathrm{K}$ or t $\mathrm{l}$ æg $\mathrm{n}$ ing (H. 26. 9., 1. 10.). Bevillinger til Sonderjylland (H. 7. 10.). Et baltisk historisk Forsk- 
nings institut, der 1. 10. 24 dannedes i Kiel forbereder Lagivelsen af en Rakke Værker (II. 13. 10.). Det sinderjydske Bind af $\mathrm{T} r$ a p begynder at udkomme ( $\mathrm{H}$. 28. 10.). P. Hjort Lorenzens $M$ in d es $m a^{2} r k$ e (H. :26. 11.). En s nestorm standser næsten al Trafik i Sunderjylland (H. :?7. 11.). 